\title{
THE MAJESTIC HADRIANIC AQUEDUCT OF THE CITY OF ATHENS
}

\author{
CHRISTAKI M. ${ }^{1}$ \\ STOURNARAS G. ${ }^{1}$ \\ NASTOS P. ${ }^{2}$ \\ MAMASIS N. ${ }^{3}$
}

\author{
${ }^{1}$ National and Kapodistrian University of Athens \\ Faculty of Geology and Geoenvironment \\ Department of Dynamic Tectonic Applied Geology \\ Panepistimiopolis Zografou, 15784, Greece \\ ${ }^{2}$ National and Kapodistrian University of Athens \\ Faculty of Geology and Geoenvironment \\ Department of Geography and Climatology \\ Panepistimiopolis Zografou, 15784, Greece \\ ${ }^{3}$ National Technical University of Athens, School of Civil Engineering \\ Department of Water Resources and Environmental Engineering \\ Iroon Polytechniou 5, Zografou, 15780, Greece
}

Received: 23/12/2015

Accepted: 30/05/2016

*to whom all correspondence should be addressed:

Available online: 09/06/2016

\section{ABSTRACT}

Athens in antiquity as well today, included all the settlements in the wider Attica region. That is why its official name was "the Athens" (plural). Since prehistoric times, the city of Athens and the wider region of Attica did not contain many natural water sources so aquatic reserves were never adequate to meet the needs of residents, as these changed through time. The construction of aqueducts was part of a more organized effort to address the water needs of the Attica basin area since prehistoric times. In the ancient city, tens of small and large aqueducts were built to meet the city's needs for water. The hydraulic structures of Athens were mostly underground, for safety reasons. The water was channeled through aqueducts to fountains. Many aqueducts were built during the pre-Roman period and they were often works of leaders or other eminent citizens of ancient Athens. A key step in developing the city's water infrastructure took place during the Roman occupation of Athens when the Hadrianic aqueduct and the Hadrianic reservoir were built. The project was a huge achievement for the time and was one of the longest tunnels worldwide during the Roman era Construction began in 125 AD and was completed in 140 $A D$. The Hadrianic aqueduct was underground with natural flow requiring a small and continuous slope along the aqueduct. Wells, communicating through the aqueduct, were placed at regular intervals.

The main branch of the aqueduct - the central part of the Hadrianic, consists of the main tunnel, approximately $20 \mathrm{~km}$ long, which starts from the foot of Mount Parnitha in the present day Olympic Village and ends up in the reservoir of Lycabettus, exploiting the water sources of Parnitha, Penteli and the Kifissos River. Gravity collected water from the water sources in the main tunnel and there was also the contribution of smaller aqueducts along the route. The secondary branches are composed of many transverse, which were designed to increase the water discharge capacity of the main aqueduct.

The Hadrianic was a project of continuous multi source collecting groundwater along its path. It was constructed below the surface at a depth of 2.5 to $40 \mathrm{~m}$ depending on the upper aquifer of the Athens basin, which fed local wells, in order to collect groundwater from that aquifer, too. The Hadrianic stopped being maintained during the Ottoman occupation and returned into service after the liberation of the city until it was gradually abandoned after the construction of modern water resource projects.

Keywords: Hadrianic, aqueducts, tunnel, wells, groundwater, water resources. 


\section{Introduction}

This study aims to highlight the bibliographic sources and research and to add new map information regarding the route and hydrogeology of the Hadrianic aqueduct.

The main purpose of Hadrian's Aqueduct was not the water supply of ancient Athens as many think, but the water supply of the Roman district of Athens. Its construction coincided with a period of drought for Athens. The region of the ancient "City of Hadrian" started from Hadrian's Gate and covered all the area of the present day Zappeio park, from the Kallimarmaro stadium till the parliament building (Fig. 1). The Romans built many public baths and wealthy citizens demanded running water in their homes. The daily water consumption per capita increased to 70 liters in the case of ordinary citizens and 500 liters a day in the case of a Roman official. A new source of water had to be found.

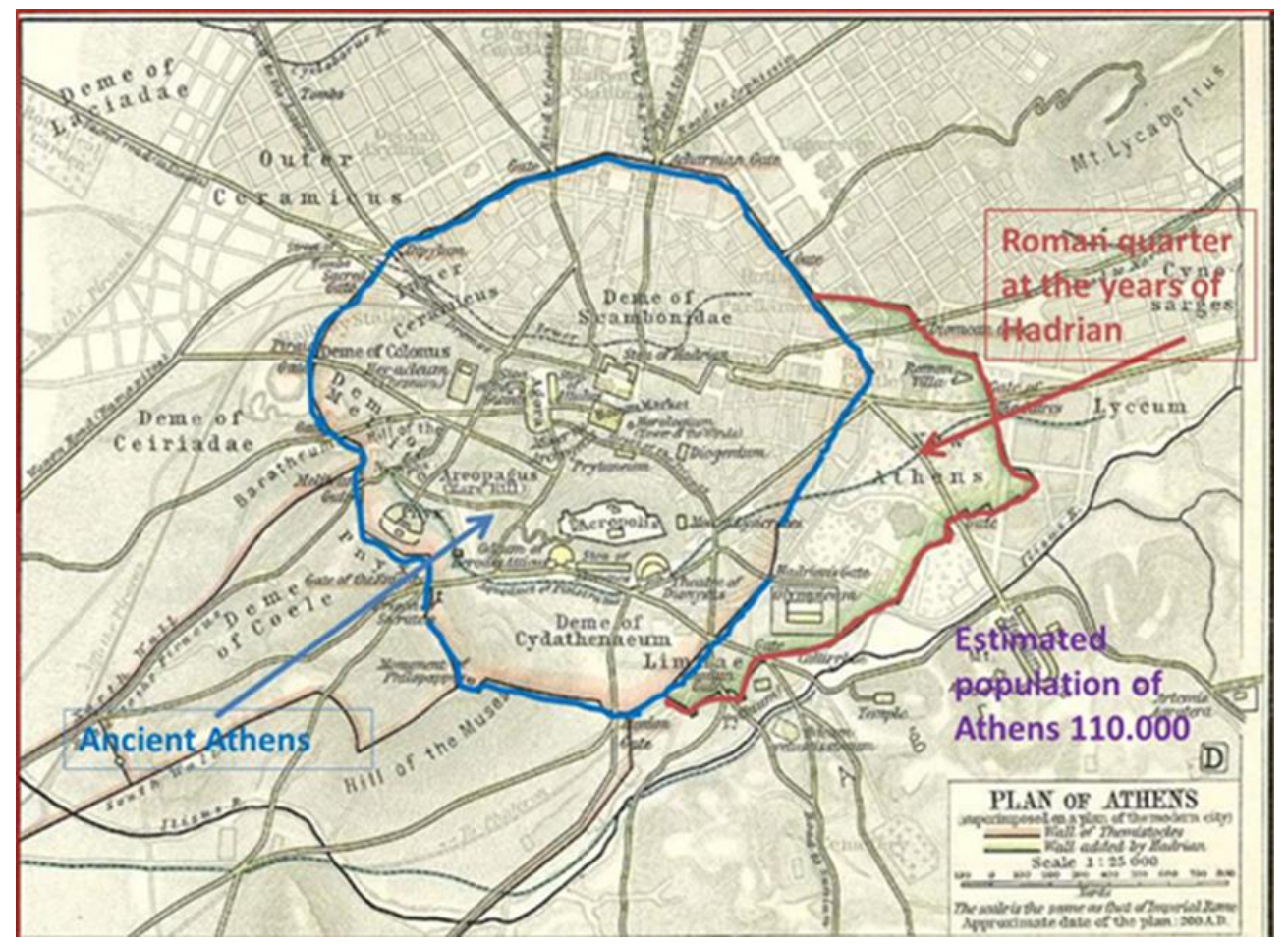

Figure 1. Ancient Athens and the extension of the City 'in Hadrian's era'

\section{Historical development of the Adrianic Aqueduct}

The construction of the water supply project for Hadrian's City from the slopes of Mount Parnitha and Penteli started in 125 AD. The project was a huge achievement for its time and constitutes one of the longest tunnels of the Roman era worldwide. This extremely expensive project was completed in 140 AD under the reign of Antoninus Pius. The Hadrianic supplied Athens with water for centuries followed by the built of the Late roman aqueduct.

The Hadrianic ceased to operate because of its abandonment during the dark ages, when in many places collapses occured and the pipes were blocked since maintenance, supervision and the cleaning services were non-existent. It was rediscovered in 1847 during works at the 'spring' of Ag. Dimitrios at Panormou street, Ambelokipi. The water found a way out because of the collapse of the tunnel due to blocked section within the Athenian Schists. Because of this, the necessary repairs to put the aqueduct back in service began. At the same time wells from which the Turks watered their fields in the area of Ampelokipoi were explored and it was found that they were connected with the ancient aqueduct. At the time, only 367 wells were found. The northernmost well is no. 367 , using the old numbering convention in relation 
to the Lycabettus reservoir or no. 299 using the new numbering approach that uses Ag. Dimitrios in Ampelokipoi as a starting point (Pappas, 1999). After the Asia Minor catastrophe (1922), Athens faced a sudden increase in population due to an influx of refugees. The population rose from 150,000 to 800,000 residents and the water supply situation deteriorated.

In 1924 the US company ULEN was awarded the Athens water supply project, providing for new water sources as well as a new water distribution system. The first concern of the company was to repair the Hadrianic aqueduct and improve its flow capacity. The aqueduct was recorded topographically, was cleaned, and was repaired across its entire length. 299 wells were recorded and numbered, all the way up to the edge of the main branch within the sloping tunnel. Moreover, major improvement projects were undertaken in order to increase the water collecting capacity of the aqueduct with wells and microdams at the springs of Kithara and Ampoli, at the area of Tatoi. An extension of the ancient aqueduct branches was also constructed for collecting water from the sources at Dimogli and Kokkinara (Kifissia). Following the improvements mentioned above, the Hadrianic was supplying water to Athens, for more than 1800 years after its construction, with an average of 2.8 million cubic meters of water a year! The aqueduct ceased to be the main source of water for Athens after the construction of the Marathon dam and the Bogiati tunnel in 1929. However it was used as an additional water source for many years after that.

In the decades 1950 - 1960 Athens was growing continuously. There was a rapid reconstruction without adequate water and sewage networks. Then, houses and industries were built literally on Hadrian's Aqueduct, and as it was designed to collect groundwater along the route, ended up receiving local waste water of the basin, rendering the water non-potable. The most recent use of the aqueduct for potable water was in the 1960s, providing water to the oil refinery built in the area of the Helidonou stream. The aqueduct was also utilized to provide water for industrial or agricultural use, most importantly for the National Garden and Pedion Areos park. In early 1970s it's been water scarcity in Athens and was made an attempt to irrigate the parks of the capital (Areos Park, National Garden) with water by Hadrianic, but the effort was stopped almost immediately because the leaves of plants turned yellow, a problem which was attributed to being irrigated with contaminated water from the wells around the area of Alexandras Avenue.

The aqueduct, hundreds of years after its construction, most likely includes partial gaps due to rockfalls, but still carries enough water to its end at Panormou street (Agios Dimitrios). The water then deflects into the Alexandras Ave. sewer system.

Today there are about 130 exposed wells in public areas or private properties. There may be more, covered with metal caps on certain roads. Although over the years the Hadrianic was overtaken by other water supply systems, it still provides water for certain uses. More specifically, it supplies the water treatment plant of EYDAP at Metamorphosis and it also supplies the municipalities of Metamorphosis and $\mathrm{N}$. Ionia with water for irrigation. Additionally, in Metamorphosis, it also provides water to industry.

\section{The tunnel of the Hadrianic Aqueduct}

The route of the tunnel was as follows: Starting from the reservoir at the foot of Lycabettus Hill, the tunnel headed to Ampelokipoi and from there followed the route of today's Kifissias Avenue, always underground. At the position Diavolorema near the Nursing Home, the tunnel followed an easterly direction until the circular tank of Halandri and from there it changed to a northwesterly path towards Heraklion and Koukouvaounes. From there, the tunnel headed down the Kifissos river and then passed from position Monopati arriving at the Souna (or Schinia) stream in Menidi. At that point, the underground pipeline was split in two, one part was directed north towards the Ampoli valley in the southern environs of the royal villa at Dhekelia and the other was directed west towards Holy Trinity of Parnitha, which is known for its rich aquifers and springs (fig. 2). 


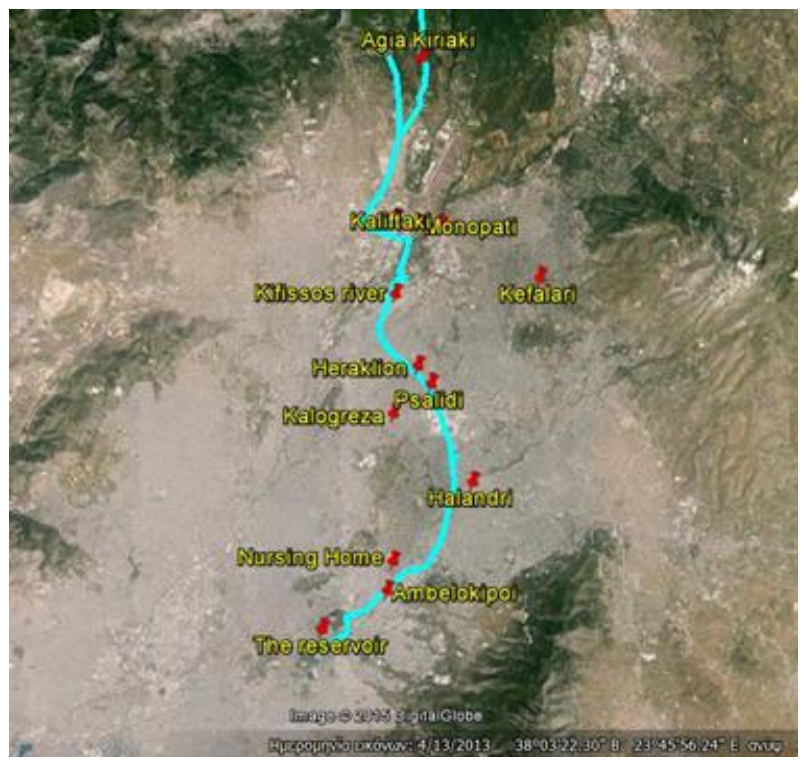

Figure 2. Detailed route of the aqueduct

The width of the tunnel, varied from $36 \mathrm{~cm}$ to $110 \mathrm{~cm}$ and the height from $1.20 \mathrm{~cm}$ to $1.60 \mathrm{~cm}$. It was constructed from bricks whose size varied depending on the dimensions of the tunnel and the shape of the domes. (A. Kordellas, 1879) (fig. 3, a, b, c, d).

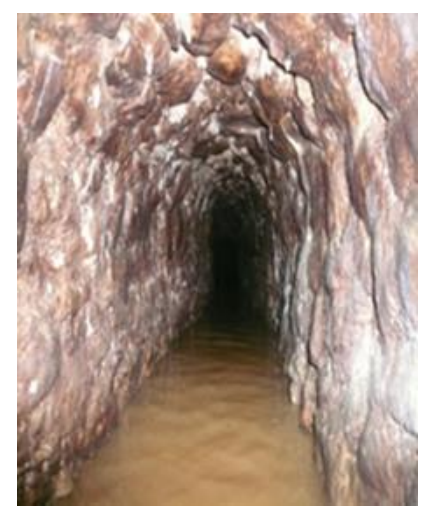

(a)

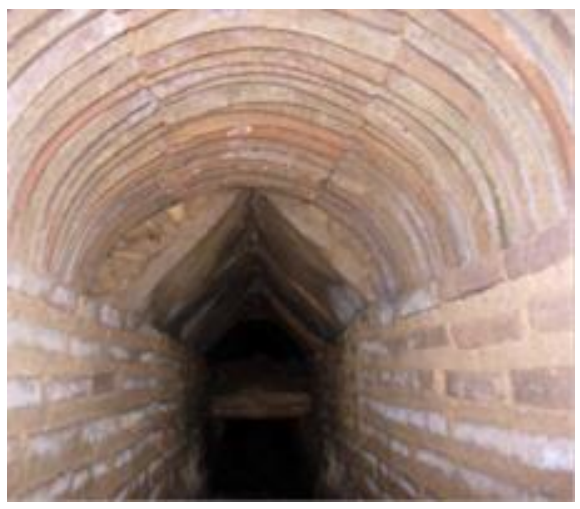

(c)

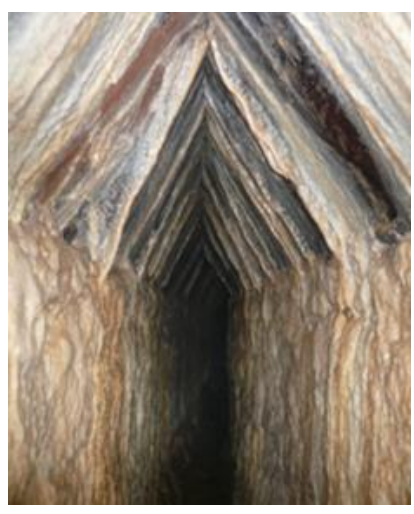

(b)

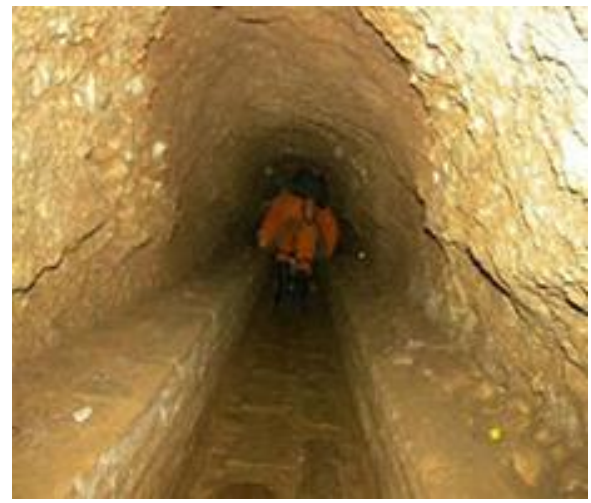

(d)

Figure 3. Featured characteristics of the interior of the aqueduct (source: P. Deftereos). The main tunnel with inflows through the walls (a). Different sections from the inside (b, c, d) 
The slope of the tunnel changes across its length. Its northern part has a slope of $~ 2,5 \%$ for approximately $1.5 \mathrm{Km}$ and it is situated inside the cones of taluses and scree (fig.4). The tunnel then becomes steeper for approximately $2.5 \mathrm{Km}$, with a slope of $13 \%$ and passes under the bed of the river Kifissos in the area of Chelidonou (fig. 5a). The tunnel's slope is then almost constant for its remaining path of $16 \mathrm{Km}$, with a slope of $\sim 2.2 \%$ from the underground junction with Kifissos until the tank at Lycabettus, (Chiotis, 2008).

The project was constructed by drilling 465 wells (10 to $42 \mathrm{~m}$. deep) along the tunnel's designated route. The tunnel was dug out from pairs of neighbouring wells and the two sections met in the middle. The average distance between wells was $35-40 \mathrm{~m}$. Many of the wells can still be identified today (fig. 6).

The wells heads of the Hadrianic were at ground level and camouflaged in order to not be easily recognizable and to be protected from the risk of water pollution, natural disasters and enemy actions. They were accessed only when cleaning or repairs were required and also in order to allow sunlight access (fig. 7).

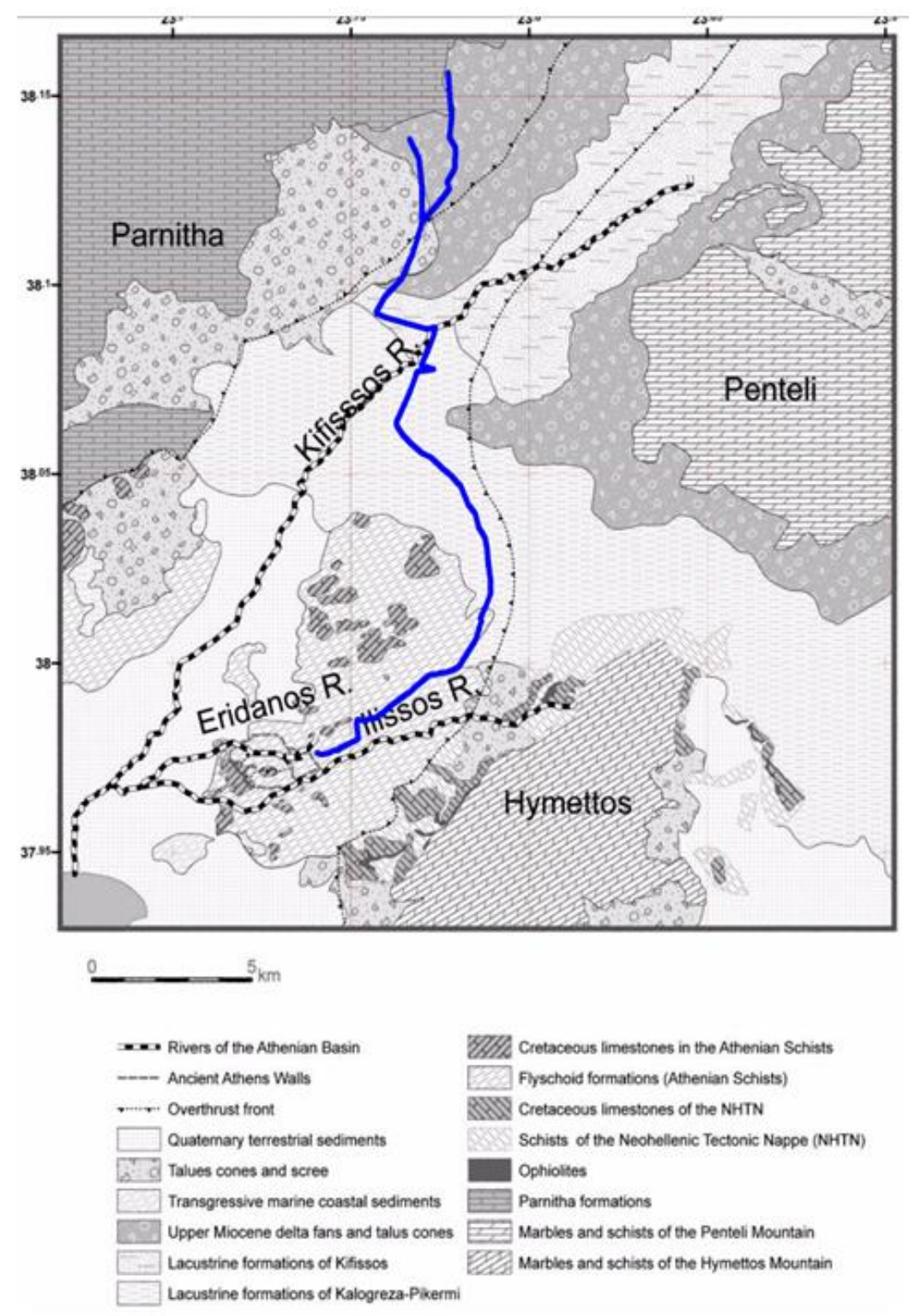

Figure 4. The main route of Adrianic aqueduct based on this study, traversing the geological formations on a simplified geological map of the Athenian Basin (after Chiotis E.D, Chioti L. E., 2012), based on the 1:50,000 maps of IGME (Institute of Geology and Mineral Exploration, Greece) 


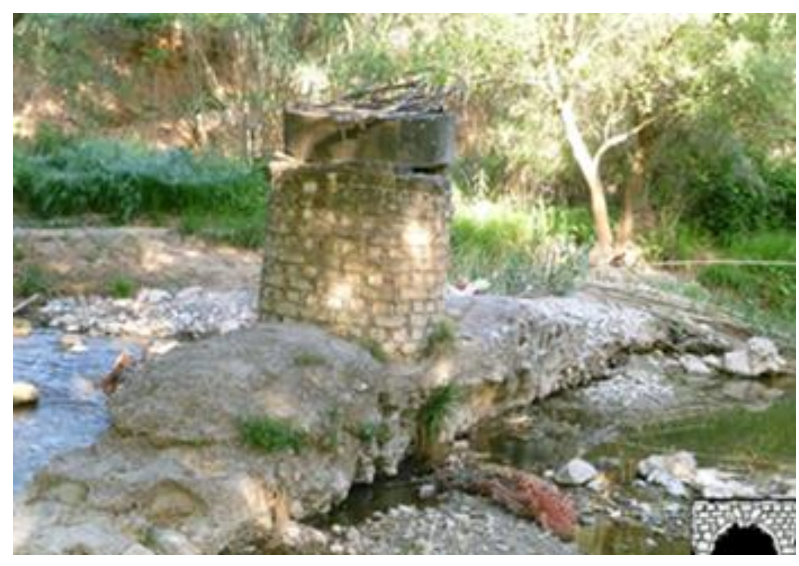

(a)

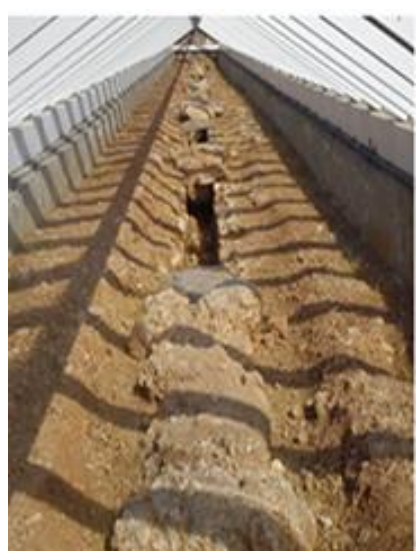

(b)

Figure 5. Hadrianic aqueduct crosses the Kifissos river via a metal pipe that was placed in modern times, avoiding the ancient section that was destroyed during a storm on 21 February 1930. There is a pressure release valve in the middle of the pipe (a). The ground channel at the Olympic village (source Ministry of Culture and Sport) (b)

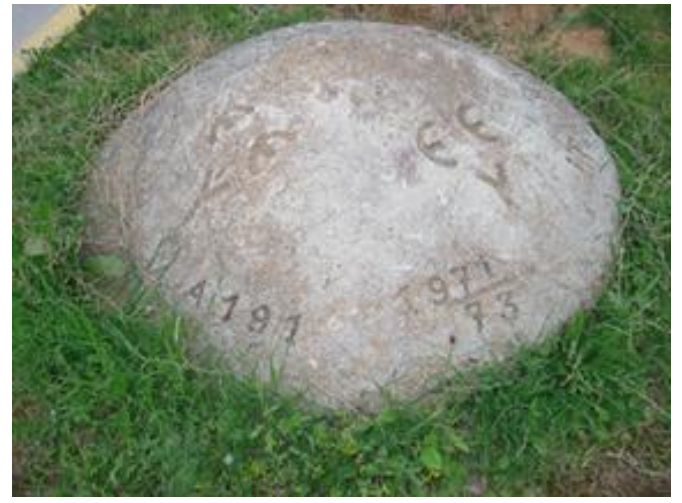

(a)

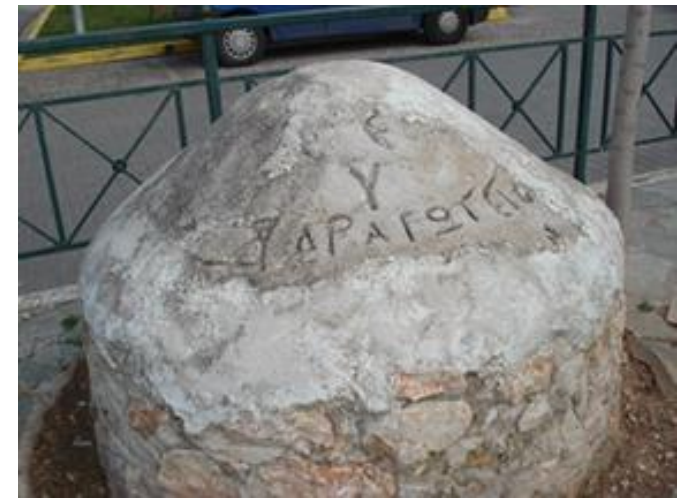

(b)

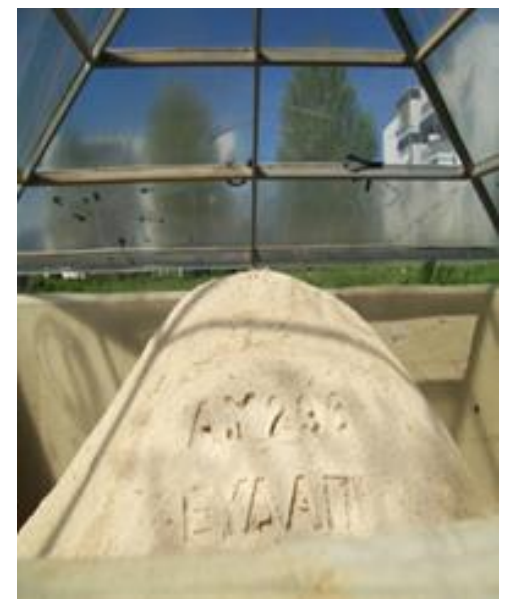

(c)

Figure 6. Wells in the City: The well number 191 (a). The word aqueduct is written on the well (b). The well 296 in the new numbering at Thrakomakedones. It has been found that under the well296, the aquifer of the cones of taluses and scree is located above watertight clay sediments (c) 
The tunnel made use of gravity to carry water into the stone reservoir at Lycabettus Hill (altitude of 136 $\mathrm{m}$ above sea level). From there, the water was distributed to the Roman district of Athens located at an altitude of $90 \mathrm{~m}$. The original tank was $26 \mathrm{~m}$ long, $9.36 \mathrm{~m}$ wide and $2 \mathrm{~m}$ high. It had a capacity of $489 \mathrm{~m} 3$. Pipes originating from the reservoir supplied water to the city in large quantities, enough to cover the needs of the Athenians at the time. Leigh (1998), believes that the tank had a dual role and also functioned as a nymphaeum. The face of the tank was adorned with four smooth lonic columns that supported the epistyle, which featured an inscription in Roman letters commemorating the pioneers of this important project for the city of Athens. Nowadays, this inscription can be seen lying on the ground just above the statue of Eynard in the National Gardens (fig. 8).
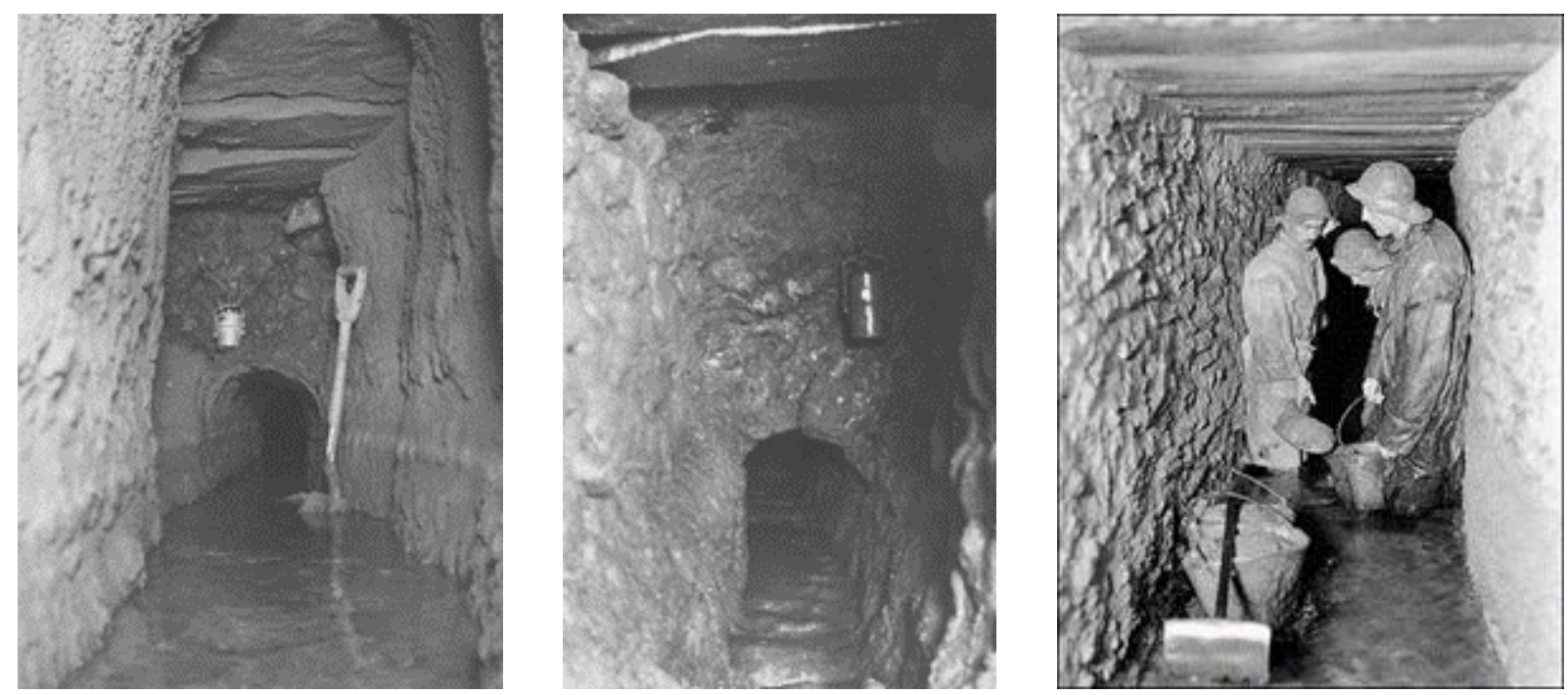

Figure 7. Cleaning works (source EYDAP)

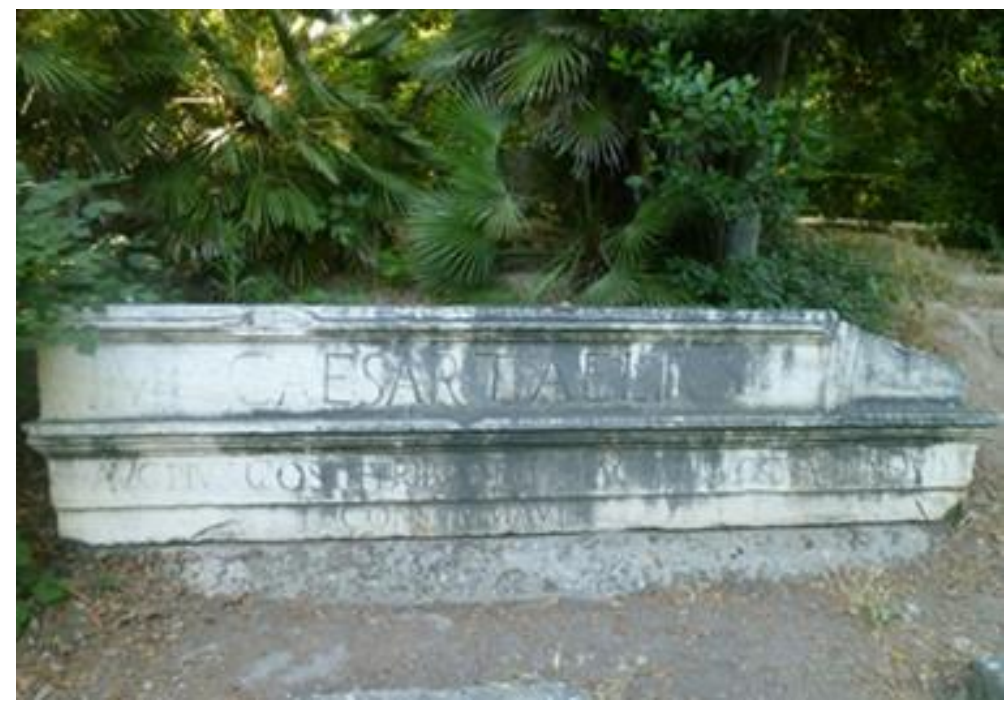

Figure 8. Surviving part the epistyle in the National Gardens of Athens

The aqueduct approached the Market from the east at a higher elevation than other aqueducts along the road south of Eleusinion. After passing under the Panathenaic Way it split into two branches; one turned west and the other north. The western branch of the aqueduct provided water to a channel that was found northwest of Areios Pagos and flowed towards Piraeus Street. The northern branch of the aqueduct was supported by arches and led to the 'Nymphaeum', north of the old Southeastern Fountain (Thompson \& Wycherley, 1972, 202 Leigh, 1998, Chiotis, 2012). 

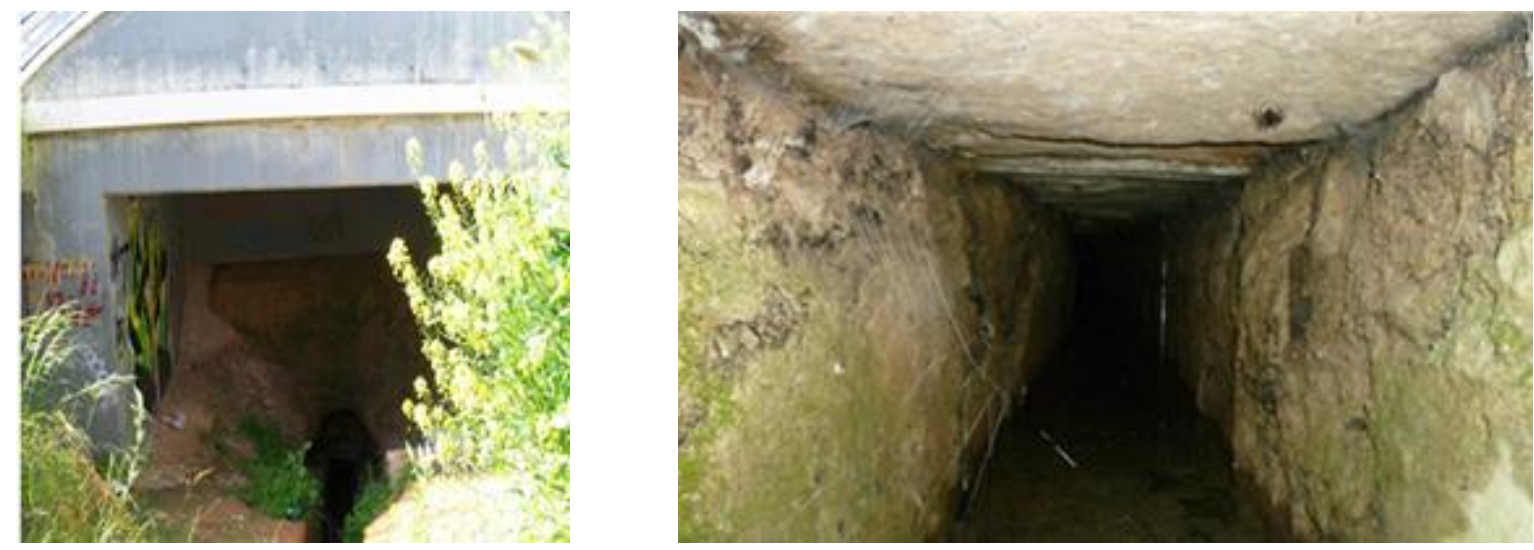

Figure 9. The end of the surface branch and the start of the underground main branch towards the Olympic village (a), and the inside of the underground canal (b)

\section{Water resources of the Hadrianic Aqueduct}

As there are more extensive studies, there is an ever-increasing understanding and knowledge that the Hadrianic was a project of continuous, multi-source water collection. It was constructed below ground at a depth of $2.5 \mathrm{~m}$ to $40 \mathrm{~m}$ depending on the upper aquifer of the basin, in order to utilize all the available water resources and groundwater wells in its path. The tunnel is connected to the surface through a $90 \mathrm{~m}$ long section built at an incline of 200 in order to collect water from the sources of the Parnitha Mountain (fig. 9, a, and b). The end of the tunnel at the northernmost well is located at a depth of $30.5 \mathrm{~m}$ and the water level is currently 20 meters, as measured at a nearby drilling (Vrellis, 2010 Chiotis, 2012). The auxiliary aqueducts include the northern surface extension of the aqueduct towards Thrakomakedones and Varypompi, built to transport water from sources at Parnitha, as well as extensions of the tunnel with local aqueducts, to transport the water from the foothills of Mount Penteli to the tunnel. Transverse aqueducts were: Halandri, Kalogreza, Brahami, Psalidi, Agia Barbara, Kaliftaki, Kefalari and Agia Kiriaki (fig. 2).The recent archaeological excavations at the Olympic Village have brought to light parts of the aqueduct that were shown on EYDAP maps but were hidden beneath a layer of earth one to two meters thick.
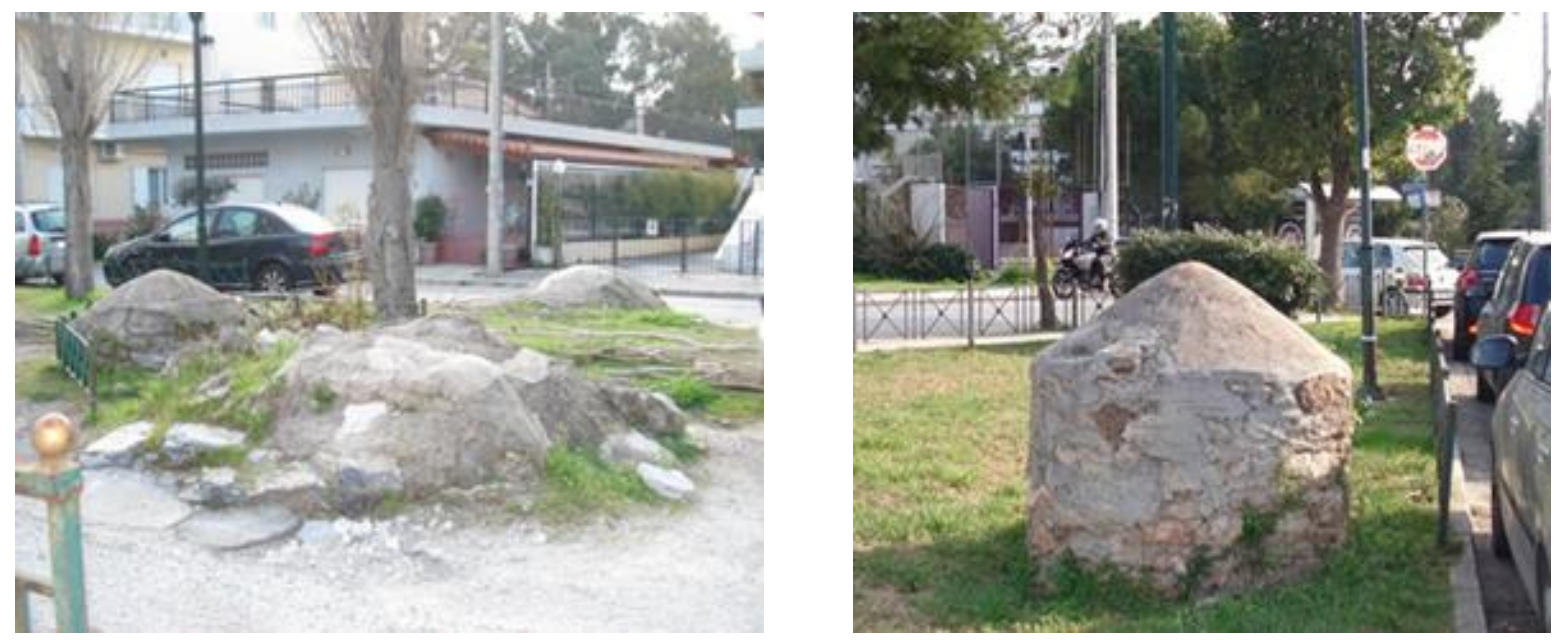

Figure 10. The beginning of Halandri transverse aqueduct. Wells at El-Alamein street, Halandri. 
The most documented transverse aqueduct is the Halandri aqueduct that fed into well 102 in today's El Alamein street (fig. 10). It is believed that it flowed into a circular tank, from which the overflow was channeled to the Hadrianic. It carried spring water from the Penteli Mountain through the stream of Chalandri, starting from the Monastery of Penteli. The construction of several side branches of the aqueduct was made at different times but most of them were built using a similar approach. The project must have been even more complex in antiquity. (Kordellas, 1879), considers that the project consisted of the northwestern tunnel and a direct water supply from the Kifissos river as well as of other branches.

The Hadrianic was dug out, as mentioned above, below the groundwater level. The tunnel starts in fan at Thrakomakedones where the aquifer of the talues cones and scree is found above watertight clay sediments (fig 4).The burrowing must have taken place upstream in order to achieve natural drainage of the water, especially in the section from the junction with the Kifissos River up to the Olympic village. Drainage was not an issue in the area of the Athenian Schists however $\alpha$ large part of the Hadrianic is located in the Athenian schist and exhibits stability problems and forfeitures. Besides, the discovery of the Hadrianic is indirectly linked to the collapse of the tunnel section built in the Athenian Schists at Panormou Street, in the area of Ag. Dimitrios in Ambelokipi. The recent archaeological excavations at the Olympic Village revealed the north surface extension of the Hadrianic which is now visitable (PlatonosYota, 2004) (fig. 11, fig. 5b).
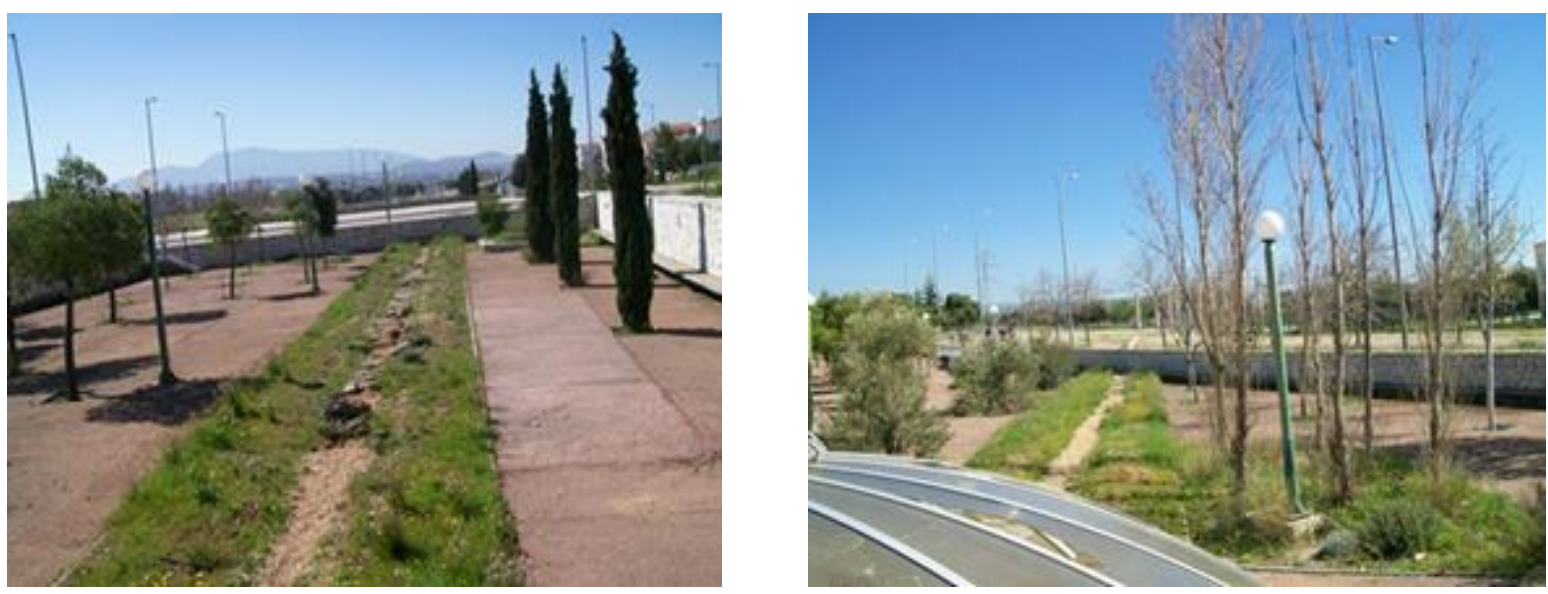

Figure 11. Featured characteristics of the surface route of the aqueduct. The northern extension consisting of two surface sectors covered grooves that collected water from the sources of Parnitha

\section{Conclusions}

The Hadrianic supplied water to Athens for more than 1800 years, making use of the water resources of Parnitha and Penteli as well as groundwater from the aquifer that it penetrates. It constituted a tunnel of continuous, multi-source water collection. The research related to its water sources and the different sections of the aqueduct is still in progress as we currently do not have a full picture of the aqueduct. Kordelas' (1879) writings, descriptions of technical projects in modern times as well as recent archaeological discoveries in the Olympic Stadium area, suggest the existence of aqueducts preceding the Hadrianic as well as more recent infrastructure works carried out by the municipality of Athens. All of these were fed and are still fed by the same sources.

The path of the Hadrianic, the depths of its tunnels and the positions of its auxiliary aqueducts reveal that the Hadrianic was the largest and most important water supply project in Athens in historical times. A project of a sophisticated technological and hydrogeological culture. It is perhaps one of the most unique technical projects with continuous use over 1800 years and should been promoted in a way that would benefit modern Greeks and infuse their patriotism and national pride. According to EYDAP, Greece should 
promote this project with photographic exhibitions, scientific discussions and other such events and not let it be lost in time.

\section{Acknowledgements}

The authors would like to thank EYDAP for providing the datasets.

\section{References}

Angelakis A.N., Koutsoyiannis D. and Tchobanoglous G. (2005), Urban Wastewater and Stormwater Technologies in the Ancient Greece, Water Research, 39(1), 210-220.

Angelakis A.N. and Koutsoyiannis D. (2003), Urban water engineering and management in Ancient Greece. The Encyclopedia of Water Science, edited by B. A. Stewart and T. Howell, pp. 999-1007, Dekker, New York.

Angelakis A.N., Mamassis N., Dialynas E. and Defteraios P. (2014), Urban Water Supply, Wastewater, and Stormwater Considerations in Ancient Hellas: Lessons Learned, Environment and Natural Resources Research, 4(3), 95-101.

Chiotis D.E. and Marinos G.P. (2012), Geological aspects on the sustainability of ancient aqueducts of Athens, Bulletin of the Geological Society of Greece, XLVI, 16-38.

Chiotis E. and Chioti L. (2011), Industrial activities in the ancient Agora of Athens in the Late Roman times. In The Agora in the Mediterranean from Homeric to Roman Time, Giannikouri, A., Ed., Ministry of Culture, Athens, Greece, pp. 181-196.

Chiotis E. (2008), Newer views on Hadrian's Aqueduct and its technological relationship with earlier Greek works ISBN 978-960-02-2675-1 995-1005, Proceedings of the $5^{\text {th }}$ Symposium of Greek Archaeometric company, Athens, Publishing Papazissis, Athens 2012.

De Feo G., Angelakis A., Antoniou G., El-Gohary F., Haut B., Passchier C.W. and Zheng X.Y. (2013), Historical and Technical Notes on Aqueducts from Prehistoric to Medieval Time, Water, 5(4), 1996-2025.

Kordellas A. (1879). The Athens examined under hydraulic view. Publishing Philokalia, Second Part. Athens.

Korres M. (2002), Hadrianic aqueduct in the water supply of Athens, Kathimerini, Seven Days (24 March 2002), 15-17.

Koutsoyiannis D., Zarkadoulas N., Angelakis A.N. and Tchobanoglous G. (2008), Urban Water management in Ancient Greece: Legacies and Lessons, ASCE Journal of Water Resources Planning and Management, 134(1), 45-54.

Koutsoyiannis D. and Angelakis A.N. (2004), Agricultural hydraulic works in ancient Greece. The Encyclopedia of Water Science.

Leigh S. (1998), The Aqueduct of Hadrian and the water supply of Roman Athens. Ph.D. Thesis, University of Pennsylvania.

Pappas A. (1999), Water supply of ancient Athens. Publishing Free Skepsis, Athens.

Paraskeuopoulos G.P. (1907), The mayors of Athens (1835-1907. Vasilike Typographia Raphtane-Pappagorgiou.

Platonos-Yiota M. (2004), ACHARNAI, Historical, and topographic overview of Ancient Acharnai, of the neighbouring Municipalities and the Parnitha fortifications, Municipality of Acharnai, Athens, Greece

Skilardi D. (2005b), Showroom Antiquities Olympic Stadium Maroussi Attica Street 2004: Excavations, Discoveries, New Museums, Athens

Tassios T.P. (2007), Water supplies of ancient Greek cities, Water Science and Technology: Water Supply, 7(1), 165-172.

Voudouris K., Christodoulakos Y., Stiakakis M. and Angelakis A.N. (2013), Hydrogeological Characteristics of Hellenic Aqueducts-like Qanats, Water, 5(3), 1326-1345.

Zarkadoulas N., Koutsoyiannis D., Manassis N. and Angelakis A.N. (2012), A brief history of water management in ancient Greece. Evolution of Water Supply through the Millennia, IWA Publishing, London, UK, Ch. 10, pp. 259270. 